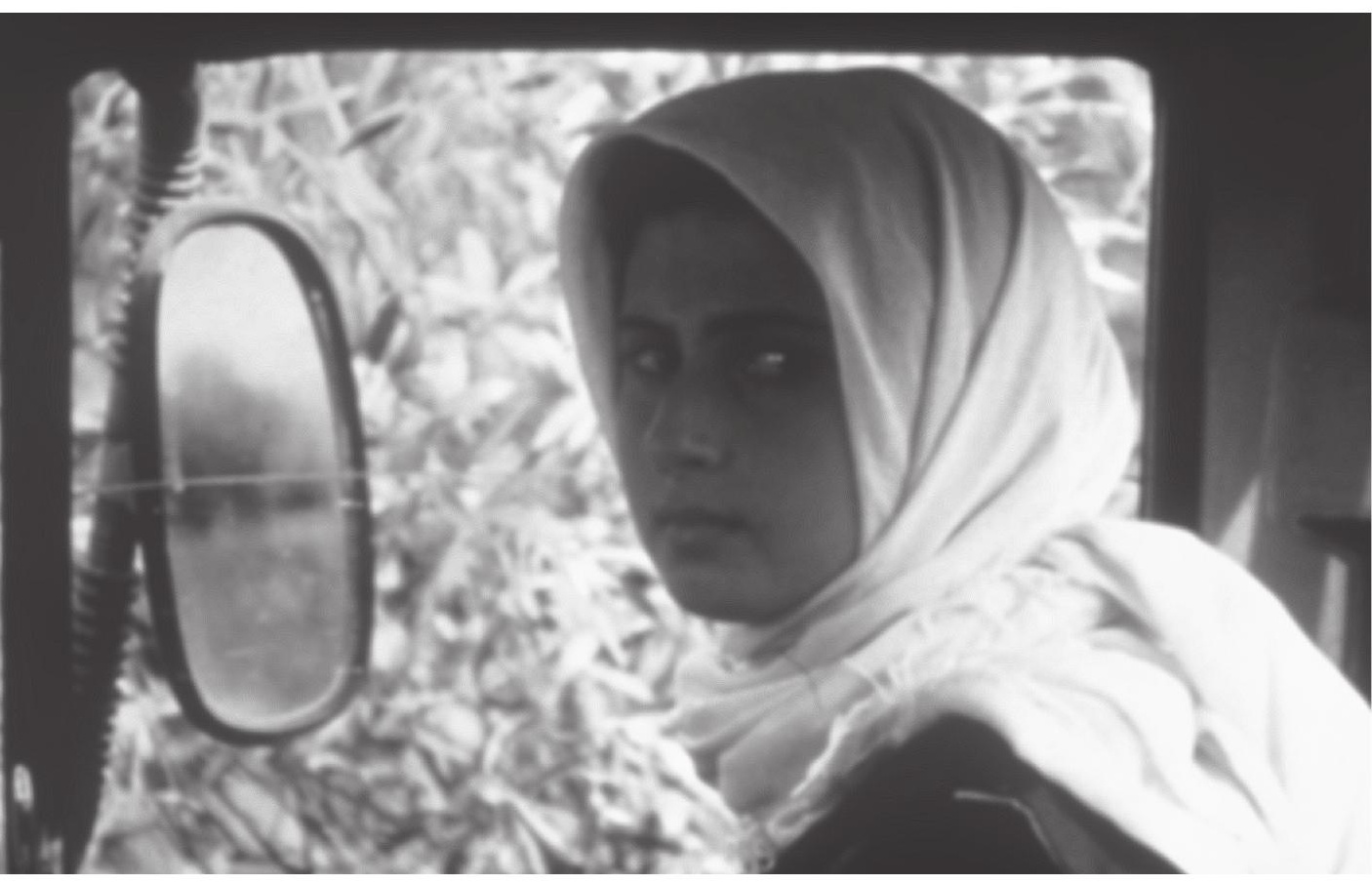

A rare glimpse of Tahereh's face in Through the Olive Trees

(Zire darakhatan zeyton) (dir. Abbas Kiarostami, France/

Iran, 1994). Courtesy Artificial Eye 


\title{
Women in a Widening Frame: (Cross-)Cultural Projection, Spectatorship, and Iranian Cinema
}

\author{
Lindsey Moore
}

This article addresses the entwined issues of gendered and cultural representation in contemporary Iranian cinema. One of the remarkable features of recent Iranian film is its allegorical use of gendered tropes, in particular the (in)visibility and (im) mobility of women in social space. The female body, which has been defined in historically charged and culturally assertive terms, is constantly reinvested thematically and technically. In Iran, as in more conventionally "postcolonial" sites of knowledge production, ${ }^{1}$ the relationship between vision and embodied, gendered objects is both culturally specific and informed by cross-cultural encounter. This article urges continued attention to the import of female representation in relation to a film's reception both within and outside of the national viewing context.

I assess the implications of verisimilitude in three films: Abbas Kiarostami's Through the Olive Trees (Zire darakhatan zeyton) (France/Iran, 1994), Samira Makhmalbaf's The Apple (Sib) (Iran/ France, 1998), and Kim Longinotto and Ziba Mir-Hosseini's

Copyright $\left({ }^{\circ} 2005\right.$ by Camera Obscura

Camera Obscura 59, Volume 20, Number 2

Published by Duke University Press 
Divorce Iranian Style (UK, 1998). The difficulty in generically categorizing these films, particularly the latter two, rests on the exploitation in each case of the hinge between documentary and dramatic technique. It is my intention not only to contextualize this strategy in relation to postrevolutionary Iranian cultural politics, but to investigate the effects of generically hybrid texts that enter the international sphere. As Laura Mulvey suggests, the modishness of contemporary Iranian cinema is partly due to its masterful treatment of the fact that "cinema is 'about' seeing and the construction of the visible by filmic convention." ${ }^{2}$ Given that any encounter between Iran and "the West" carries an ideological charge, however, ${ }^{3}$ the political valence of representation remains more precarious than an explicit demarcation of the distance between signifier and referent would resolve. This article demonstrates Mulvey's assertion but presses upon the issue of woman as the perennial bearer of filmic and national or cultural meaning. I argue that, once subjected to a cross-cultural viewing dynamic, Iranian women on screen continue to signify ethnographically as the "always already known.” Trinh T. Minh-ha's pithy formulation that "there is no such thing as documentary" 4 enables us to trouble the epistemological comfort zone of non-Iranian spectators (such as myself), but also to assess the representational strategies that shape the film text at the point of its origin. Thus I reconsider the relationship between film and the phenomenal, particularly in cross-cultural viewing contexts.

Kiarostami's Through the Olive Trees opens, before the credits, with the self-introduction (addressed to the camera) of Mohamed Ali Keshawarz, the actor who plays the director, followed by his attempt to select, from a crowd of young veiled women, a female protagonist for the film-within-a-film, which is the embedded narrative of Olive Trees. ${ }^{5}$ The scene combines panning and close-up shots on the women's faces as they intone their names and (lack of) addresses. Olive Trees is the third installment in a trilogy based thematically on the devastating earthquake of 1991 in Roudbar, north of Tehran. ${ }^{6}$ (Subsequently, the voice of a male characterwhose identity is not revealed-makes an intratextual reference 
to the first film and comments ambiguously that he does not like cinema or art, "but because of the earthquake." It is unclear whether he chooses to participate in the film and, if so, whether his decision is motivated financially or by the desirability of representing the event to the outside world.) The opening scene, which functions as mise en abyme to denote the processes of the film as a whole, foregrounds the haggling agency of the young women. ${ }^{7}$ After Mrs. Shiva (Zarifeh Shiva), the director's assistant, interrupts his posturing with the pragmatic reminder of the need to hurry up as the "girls are hungry," the movement of the director and camera through the crowd emphasizes the individual identities of the identically dressed and veiled respondents. It then incorporates a reversed perspective. The director, now the object of scrutiny, is challenged by the girls, who refuse to stay in orderly lines. They ask, "Where will you show it? You're filming us. . . O Oh, what does it matter?" and then accuse him, "You won't show it. Are you going to show it to us? Your last film went out on Channel 2, which we can't get here. Why bother?" Eventually they decide, however, "We film! But you'll have to show it!"

Kiarostami's films typically feature multiple focalization, a blurring of the line between fictional events and characters and those "drawn from life," and the reflexive framing of films within films, all in order to sustain a resistant perspective on the process of filmmaking. Rather than being purely formalist strategies, these techniques can be understood as an engaged commentary on the act of viewing; in the scene just discussed, issues of who and what is filmed and who gets to watch are considered not only intrinsic to the finished product but also open to negotiation by the participants. As such, it demonstrates the mutual influence of textual and public realms and foregrounds the Kiarostami credo: "We are never able to reconstruct truth. ... So if we distance the audience from the film and even film from itself," the audience is reminded that "we are reconstructing reality." Kiarostami believes that "it is the audience who should seek the answer" to any text and that, by insisting upon defamiliarization, "cinema and all the arts ought to be able to destroy the mind of their audience in order to reject the old values and make it susceptible to new values." 8 
Some commentators have challenged Kiarostami's metatextual and self-reflexive propensities. Azadeh Farahmand, for example, cites a minimal use of female characters as evidence of Kiarostami's "political escapism [that is] a facilitating, rather than a debilitating, choice, one which caters to the film festival taste for high art and restrained politics." Through the use of mediating characters and rural landscapes, "the viewer can maintain his $[s i c]$ distance and remain uninvolved, be fascinated, securely appreciative." ${ }^{9}$ As Trinh points out, if films are seen only as artificial constructs, then the social interactions and practices represented remain "framed" or resistant to political challenge. ${ }^{10}$ However, in foregrounding the way Kiarostami reflects an international taste for "exotic" landscapes, Farahmand overlooks his equally insistent focus on communities in transition as a result of the forces of nature and modernity. She also underestimates the extent to which, as Negar Mottahedeh points out, subversion is written into the fabric of Kiarostami's films, which encourage the spectator to imagine what lies outside the frame or is not ascertainable to the gaze-hence to question accepted limits of representation. ${ }^{11}$

An analysis of the thematic and specular focus on women in Through the Olive Trees productively troubles Farahmand's critique. The film suggests that women manipulate visual codes and strategically use silence in a complex and variable relationship to both social and representational practices. The fact that the film begins with close-ups on women's faces in 1994 is, given the ideological context I discuss below, a relatively radical gesture. Moreover, the scene opens onto a film that is thematically and structurally concerned with the ways female perspectives on events exceed the filter of the male, intradiegetic filmmaker. This is discreetly signaled in the driving scene subsequent to the credits. The camera, facing outward from the dashboard, aligns the spectator's perspective with that of Mrs. Shiva and deflects our engagement with that character from her face to her voice. Infrequent reverse shots focus obliquely, via the car's side mirror, on the faces of those who speak to her, including some young boys. This tendency to defer spectatorial satisfaction is replicated in relation to 
the female love interest, Tahereh (Tahereh Ladanian), who plays the wife in the embedded narrative of Hossein (Hossein Rezai), her frustrated suitor in the "real life" framing narrative. Tahereh refuses to return either the gaze or conversational overtures of Hossein; indeed, she assents to complete the dialogue between them required by the "fictional" script only when threatened with the loss of her part. Her constantly averted face and determined silence exacerbate Hossein's yearning as well as viewer curiosity; the film is ultimately about Tahereh because both she and her response to the events unfolding about her remain enigmatic.

Mary Ann Doane has memorably theorized the function of veiling mechanisms in enhancing women's desirability as screen fetishes, arguing that a supplementary surface over the face "functions to hide an absence" — castration or (lack of) truth-and signifies "a dangerous deception of duplicity attached to the feminine." Doane, however, indicates that her approach is restricted to the trope of the veil in Western discourse, a caveat that is applicable here. ${ }^{12}$ Tahereh's strategic elusiveness is not intended to mystify and hence eroticize the figure of "woman." Rather it represents a trenchant assertion of Tahereh's right to choose her own suitor rather than to be pursued. Her oft-mentioned stubbornness and sense of self-worth rest on her self-fashioning as literate, educated, and modern; similarly, she resists wearing the costume assigned to her on the grounds that "she's a student, not an illiterate peasant" and "no one wears dresses like that anymore." It is noteworthy that, with one exception, she refuses to return the look of Hossein and the spectator because she is reading. The potential of the crowd at the start of the film to assert agency through a command of the word and to assert the right to see rather than be observed is thus realized through the female protagonist. Her elusiveness does propel the narrative by exacerbating a desire for romantic closure, but this, too, is ambiguously realized. The final scene culminates in an extreme long shot in real time in which Hossein follows Tahereh into the distance and then begins to return alone. Does she maintain her aloofness, or is he returning to tell the film crew of his success? This final scene exceeds the perspective of the homodiegetic film narrator and thus our own. 
Although the means are fictional, Kiarostami's crowd of veiled women, Mrs. Shiva, and Tahereh function as agents in a rich and complex filmic history, which, since 1979, has been centrally concerned with female representation. Through the Olive Trees demonstrates an internalized sensitivity to gendered codes that has necessitated a strategic reconsideration of the implications of the viewing act per se.

From its inception, the content of Iranian cinema has been strongly influenced by a dominant national political ideology. Since the Iranian Revolution of 1979, as in the Pahlavi era, the state has censored political dissent and provided financial support for films that positively reflect government policy. ${ }^{13}$ Iranian cinema's greatest crisis came in the buildup to the revolution, when the clergy defined film as an agent of cultural colonization, and arson attacks were made on cinemas throughout the country. The industry was resurrected, however, because the Islamic state recognized its value in transmitting both ideology within Iran and a more benevolent national image beyond its boundaries to offset the negative stereotypes produced through the Salman Rushdie affair and the hostage crisis of 1979-8o. The number of postrevolutionary films screened at foreign festivals increased dramatically, from 2 in 1986 to 230 (of which 11 garnered awards) in 1990. However, Iranian cinema has thus far not proved itself to be viable economically without foreign markets and, in many cases, cofunding. Moreover, as Hamid Naficy observes, the striking success of contemporary Iranian cinema has not mapped back onto a commensurate improvement in the international profile of its government. ${ }^{14}$

Subject matter is scrutinized in a tiered censorship system monitored by the production and distribution house Farabi Cinema Foundation under the Ministry of Culture and Islamic Guidance (Ershad). The most recent trend in the industry is a relaxation of controls, due in part to the challenges to censorship posed by new technologies (video, DVD, and satellite), but also to relative liberalization under Hojjatoleslam Mohammad Khatami (minister of culture and Islamic guidance until 1992 and president of the republic since 1997). Reflecting ongoing political debate and the inconsistent application of ambiguous rules, cin- 
ema and related technologies exist within what Naficy describes as "a fluid cultural space in which all kinds of slippage and transgressions, as well as countermeasures, are possible" (55). Moreover, Iranians in exile, who form a politically and ideologically varied group but tend to be opposed to the conservative faction of the regime, contribute enormously to the total output of that which is categorized as Iranian cinema.

In the case of films produced within the country, all gendered representations and interactions are considered suspect. According to regulations imposed in 1982 , women in Iran must be visibly chaste. As justified officially by their social status, exemplified by but not limited to the raising of children as responsible Muslim citizens, women must not be treated as commodities or sexual objects. ${ }^{15}$ Landmark regulations approved in June 1982 reflected the official Islamization of the cinema and led to a precise stipulation, early the next year, of the female imagery allowed on film, including the wearing of hijab (modest dress) at all times to cover all parts of the body except the face and hands. Close-ups on a woman's face, any sexual connotation, and all physical contact between men and women were prohibited, and severe constraints were laid upon other forms of cross-gender communication.

This background of representational containment serves to contextualize Through the Olive Trees. It also illustrates Naficy's argument that Iranian official discourse rests on an "injection theory" of cinematic power, in which the line between reality and representation is assumed to be permeable and unmediated (44$45)$. As such, images of unveiled women are thought to contribute to the moral corruption of men and greater society. Iran's history of imperialist domination is explicitly harnessed to underlying assumptions about threatening female sexual presence..$^{16}$ Afsaneh Najmabadi explains that, in the buildup to the revolution, the "gharbzadeh ['westoxicated'] woman came to embody at once all social ills: she was a super-consumer of imperialist/dependentcapitalist/foreign goods; she was a propagator of the corrupt culture of the West; she was undermining the moral fabric of society; she was a parasite, beyond any type of redemption."17 By contrast, concealed and thus "cured" female bodies became a conduit for notions of communal purity and therefore subject to social sur- 
veillance. "Warrior brother" and "veiled sister" were complementary and officially sanctioned gendered identities, which emerged within revolutionary society, symbolizing persistent militancy, ethnoreligious pride, and asceticism. ${ }^{18}$ Thus the Iranian chador (black head and body cover) was dialectically reconceived in 1979, as was the Algerian haïk in the Algerian War of Independence from France (1954-62), in terms of resistance to colonial or imperial control. Although Iranian women were construed as active players, their role was sternly defined by symbolic parameters that paradoxically defined women sartorially, and hence corporeally.

However, the most common sign of revolutionary participation, the chador, emerged alongside other politically nuanced forms of veiling that disappeared from the postrevolutionary scene. The term hijab has subsequently come to replace chador, not only in Iran but also as a transnational term for "Islamic veil." Anne-Emanuelle Berger observes that this "discursive shift points to the successful reclaiming of the national revolution in Iran by a transnational pan-Islamic movement."19 Hijab thus signifies a complex, contemporary relationship between local culture and transnational, politicized religious practice. Nevertheless, specifically Persian/Iranian (as distinct from Muslim or Islamist) cultural characteristics remain pertinent to the context under discussion. Naficy proposes a dominant etiology of the self in which an inner, reliable, stable "core" is separated from an outer, variable, unreliable, and easily influenced "shell." A "boundary zone, veil or screen" protects the core from contamination and from "leaking" to the outside or being revealed. Defensive strategies such as dissimulation, evasion, masquerade, and ritual courtesy are the social norm. Naficy concludes that veiling "is operative within the self" and so "is pervasive within [Iranian] culture," a point astutely made in Kiarostami's representation of the enigmatic Tahereh. ${ }^{20}$

Private and public spaces are similarly mapped by binary codes that include lawful/forbidden contact (related to rules of kin). Naficy comments that veiling as a social practice is never "fixed or unidirectional" but that both women and men "see and organize the field of vision of the other" $\left(5^{\mathrm{o}}\right)$. He elaborates: 
For every stratagem of veiling . . there is one that violates it or plays with it, turning the veil not only into a powerful semiotic and political icon, but also into a dynamic instrument of power, sexuality and transgression. ... Walls and veils may segregate people but ... they tend to provoke curiosity and to offer visual pleasure by exhibitionism and voyeurism. ... By playing with the veil, [women] create the necessary distance that promotes scopophilia (pleasurable looking). At the same time, these strategies turn them, as the subjects of scopophilia, into erotic objects, thus, ironically, subverting the rules of modesty and the religious 'commandments of looking', which are designed to prevent women from becoming sexual objects. ${ }^{21}$

Naficy's description of ways that the veil can be wielded to manipulate and control voyeurism and exhibitionism suggests not only that women are the predominant objects of the gaze but that this is a position they encourage. As we have seen, Kiarostami's Through the Olive Trees encodes multiple modes of looking but disseminates the agency of the look to men and women, subverting an economy that would link vision, either within the film or by the spectator, with the promise of satisfaction. Moreover, if interaction between men and women is regulated by a culturally specific Symbolic, this has significant social variations and is constantly renegotiated. ${ }^{22}$ If we read Mohamed Ali Keshawarz of Olive Trees as a fictional stand-in for Kiarostami, then the former's cosmopolitan ignorance of the local custom of withholding women's names from all but their nearest kin may be an ironic comment on the difficulties of representing "Iranian" reality.

Revolutionary discourse itself was not univocal. Ali Shariati, an important intellectual mouthpiece for the revolution, had promoted the figure of Fatemeh, the Prophet Mohammad's daughter, as an alternative to the problematic model of the "westoxified woman." But revolutionary women, eventually hailing from the entire social spectrum, politicized the figure of Zeynab, Fatemeh's daughter, as the archetype of women's militancy rather than piety. That the voluntary donning of the chador was strategic and contingent is indicated by the fact that, once the Shah had fled the country in early 1979, women removed what had been predominantly an anti-Pahlavi symbol. As Naghibi argues, this did not pre- 
vent a series of repressive veiling measures being legislated in the immediate aftermath of the revolution, culminating in the Veiling Act of $1983\left(5^{6} 5^{-66}\right)$. This has been, at times, violently enforced, often by female agents (as referenced in Tahmineh Milani's film Two Women [Do Zan] [Iran, 1999] when a female vigilante on the streets of Tehran hectors the female protagonists to cover their hair properly). ${ }^{23}$

The imposition of hijab, signifying in terms of social organization as well as sartorially, has politicized women's presence in the cinema industry. Films in the early 1980 os were characterized by the cutting or blocking of images of unveiled women and by a pervasive absence of female characters. The mid-eighties saw the "pale presence" of women as background figures, filmed in long shot and passive roles. Since the late 1980 , however, women have had a more dramatic presence in both diegetic and directorial roles. ${ }^{24} \mathrm{Com}-$ mentators affirm, against the prevailing Western stereotype, that Iranian women are now massively visible in every aspect of Iranian life. The increase in the number of female directors of major popular and art-house films since the late eighties is, to some extent, a result of the incorporation of hijab in production contexts (witness Kiarostami's Mrs. Shiva as a fictional example). As Ziba Mir-Hosseini explains, "Paradoxically, the enforcement of hejab became a catalyst: by making public space more morally correct in the eyes of traditionalist families, it legitimized women's public presence."25

In this context, Jaafar Panahi's The Circle (Dayereh) (Iran/ Switzerland/Italy, 200o) sounds a warning note. The film follows a group of escaped female prisoners around Tehran, emphasizing their frustrated attempts at invisibility and flight from the city. The women's unexplained criminal statuses are extended allegorically to enable a broader exposé of authoritarian surveillance mechanisms and social practices in which men must officially account for women's presences. In frequent scenes, the women cover their faces with the chador in order to achieve anonymity within the crowd and thus to avoid the police who seem to lurk at every corner. However, anonymity is decoupled from agency. Because female students cannot take public transport out of the city without the permission of a husband or father, one of the central characters, Nargess (Nargess Mamizadeh), fails to realize 


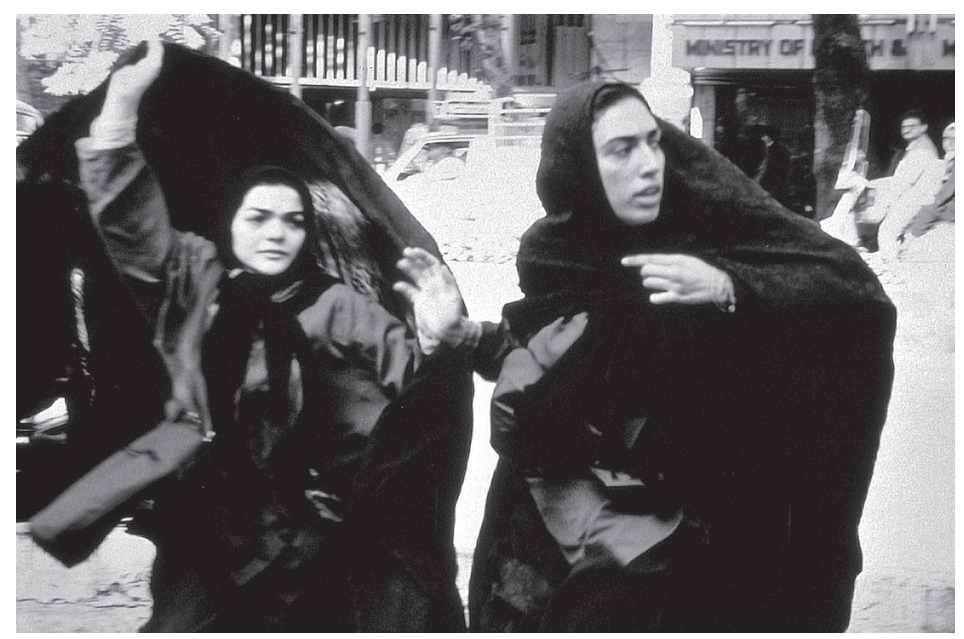

Jaafar Panahi's The Circle (Dayereh) (Iran/Switzerland/Italy, 2000). Courtesy Artificial Eye

her dream of escape to the countryside. She eventually obtains a ticket out of town but is too fearful to board the bus. Panahi uses bird's-eye perspectives, confined spaces, and a circling camera to emphasize the claustrophobic psychogeography of the bus station, in which passages and staircases lead nowhere, doors are barred, and police are pervasive. This exposure of the effective internalization of social surveillance debunks both Naficy's erotics of the frustrated gaze and assumptions that hijab equates to unmediated female public presence.

In relation to the presentation of women on-screen, the rules of hijab dictate a constant awareness of two spectator positions, that of the audience member (as unrelated to the woman on the screen) and that of the male character (who, even if related diegetically, is constrained by extradiegetic codes of viewing conduct). This necessitates new strategies for enacting gendered interplay and, by extension, maintaining plot and character credibility. In Rakhshan Bani-Etemad's The May Lady (Banoo-Ye Ordibehest) (Iran, 1998), for example, the female lead veils in front of her son because the actors are not related, which undercuts the diegetic family relationship. The same film, however, both parodies and transcends visual taboos. When the son gives his mother, Forugh, 
a pair of earrings, she puts them on under her headscarf and asks, rather farcically, how they look. Forugh manages to conduct a romantic relationship with a doctor on the telephone in which, although the lovers are never seen on-screen together, allusions and nuances push the boundaries of officially defined propriety. This technique undermines the efficacy of patrolling gendered, visual interaction by foregrounding an alternative erotic dynamic of speaking and listening. ${ }^{26}$

While it is necessary to problematize a relationship between political repression and artistic creativity, it is clear that the close monitoring of images has had some practical benefits for the national film industry, not least through the severe restrictions placed on imported films. The banning of song, dance, and sexual reference, formerly the staples of Film Farsi, has contributed to the flourishing of art-house cinema. ${ }^{27}$ Milani's immensely popular films, in which feminist themes resonate through melodramatic plots, suggest the potential for, but also dangers of, crossover genres. In August 2001, Milani was jailed on the premise that her latest film, The Hidden Half (Nimeh-ye penhan) (Iran, 2001)—which deals openly with the social legacies of the 1979 Revolution and portrays aggressive and sexually confident women-was counterrevolutionary and un-Islamic. The film had been approved by Ershad and screened to sold-out audiences in Tehran until its removal after one month. ${ }^{28}$ The script for Two Women, completed in 1991, was not approved for years on the (erroneous) grounds that it unsympathetically portrays men. Milani exploits the binary notion of the self as privately conceived and publicly monitored in this film. She employs alter-ego characters in order to illustrate the range of choices potentially available to women. ${ }^{29}$ Fereshteh (Niki Karimi), whose name means "angel" in Persian, is unable to rebel and seek a fulfilling relationship with a man as an equal, as her friend Roya (Marila Zare'i) does. Ironically, the well-behaved Fereshteh becomes the target of a stalker, whose intrusive look extends to violence when he jealously throws acid at Fereshteh's cousin's face, assuming him to be her boyfriend. The incident is richly allusive, suggesting that female desire is active and specular but inherently excessive. Even Kiarostami's Hossein accuses Tahereh of leading him on with "a look," an asser- 
tion that is not, however, confirmed within the diegesis. Mohsen Makhmalbaf's Gabbeh (Iran/France, 1996) is organized around the yearning gaze of the eponymous heroine for her distant or mythically projected lover. (He is "like an illusion," in her words.) The film employs the frustrated desire of its heroine to comment allegorically on social hierarchies and restriction. The lover thus symbolizes escape from a system in which Gabbeh's needs are constantly frustrated by the priorities and hierarchies of the clan (her father's return from the city, her grandmother's death, her uncle's wedding, and her mother's pregnancy). Gabbeh was banned in Iran until early 1997 due to the emphasis, in this seemingly innocuous film, on female desire, despite the fact that the two characters are not shown in the same frame until they depart on horseback near the end of the film-and then only in long shot.

While Milani has achieved notoriety outside Iran due to her arrest, neither her work nor that of Rakhshan Bani-Etemad, Iran's foremost documentarist of urban life, is well known internationally. Farahmand usefully emphasizes the socioeconomic and institutional factors that have led to the celebrity status and selfreflexive styles of directors such as Kiarostami and the Makhmalbaf family. Many Iranian directors actively target the international market; the fact that Kiarostami films screen earlier and more commercially successfully abroad than in Iran is obliquely alluded to in the demands of the young women at the start of the film that they should constitute its primary audience. ${ }^{30}$ Hadani Ditmars, drawing on a roundtable discussion at the 1997 Fajr Film Festival in Tehran, proffers a summary and critique of the ongoing debate over audience-oriented content: "There's a vast difference between what the Iranian public likes to watch and what European art festivals screen. . . Certain less well-known Iranian film-makers in the audience complained that the directors famous in the west pander to European tastes and don't show authentic Iranian reality. But how does one define Iranian reality, which is so much less monolithic than either American political propagandists or Islamic Revolutionary apologists pretend?"31 The cited recourse to authenticity and the objection to superficial images of Iran may appear somewhat at odds with Naficy's model of a Persian "core" self that must remain concealed. To map a psychosocial etiology 
onto the function of a nationalist imago, however, would be to conflate analytical categories. Stuart Hall's suggestion that postcolonial representational work tends to "keep these two ends of the chain in play at the same time-over-determination and difference, condensation and dissemination" is applicable here. ${ }^{32}$ That is, the will to represent multiple and often contradictory social realities is enmeshed with the need to respond to already existing, received, and often pejorative ideas. Nevertheless, the assimilation of films into preconceived aesthetic or ideological categories at the point of reception can occlude the variety and development of national cinemas; as such, continued work on diverse representations of Iranian (post)modernity is obviously desirable.

It is worth adding that the work of any director tends to develop technically and thematically. Kiarostami's extraordinarily minimalist Ten (France/Iran/US, 2002) uses confined space and gendered thematics to comment more overtly on social issues than do his previous films. Shot from the dashboard of a car and cutting between one camera pointed at the female lead and another at the passenger seat, Ten presents a divorcing woman at the center of a nexus of interrelationships, ranging from familial to random and transient associations. Sexist social attitudes are evident in her son's belligerence and parroting of her estranged husband's abuse. This is interrupted by dialogue between the woman and her sister, friends, and diverse other women, including a prostitute, a young woman who shaves her head, and an elderly woman on her way to the mosque. Both literally (through her seemingly random driving) and structurally (through the presentation of the film in ten chapters), the female protagonist is shown negotiating a contradictory urban modernity. The viewer's inconsistent access to her face, as she alternately wears and takes off sunglasses and rearranges or lets slip her headscarf, indicates what Naghibi describes as a common practice of actively "playing with the categories of self-effacement and performance, modesty and vanity." The bad-hejabi disturbs the reductive veiled/unveiled binary of oppression and resistance still assumed in non-Muslim overfreighted conceptions of "the veil." ${ }^{33}$ As such, material and supplementary veils in Ten point beyond the sartorial self-representation 
of one woman to signify catachrestically, in Gayatri Chakravorty Spivak's terms, as "concept metaphor without an adequate referent" in the cross-cultural encounter. ${ }^{34}$

While it is problematic to generalize a "native informant" position, Iranian women do engage dynamically with their complex environment and assert the need to localize the politics of feminism. In contemporary Iran, conceptions of gender are constantly changing as a result of internal debate among different factions of the clergy, women's groups, associations and journals, and work produced by Iranian emigrants. ${ }^{35}$ Cinema has proved a powerful means of displacing official discourses through the metonymical use of "woman" to signify broader social issues and to transgress the limits of censorship regulations. This may lead, however, to the displacement and deferral of the experiences, limitations, and demands of women's lives; as Farahmand suggests, the repeated visualization of "women's plight" can lead to one-dimensional characters and repetitive thematics. ${ }^{36}$ Moreover, while productive theoretical debates have taken place recently on the subject of relatively valorized forms of women's agency in diverse cultural contexts, ${ }^{37}$ I suggest that a certain fascination remains with images of "other" women as cultural victims. In order to demonstrate this phenomenon, I turn to Samira Makhmalbaf's The Apple.

Makhmalbaf's precocious talents, her family's film credentials, and the unusual subject matter and presentation of her first full-length film captured the imagination of international audiences. ${ }^{38}$ The impetus for The Apple was a television report on the Naderi family, who lived in a deprived district of Tehran and had become entangled with social welfare in a child-custody case. Because the family had already been critically represented in the popular press, the premise of the project was to fill out the case with nuance, sympathy, and attention to change. Makhmalbaf contacted the family through a welfare center, obtained permission from the father, and began filming ten days later as the girls were about to be released. 
The plot is simple: Concerned families in the neighborhood petition the local director of welfare about the neglect and virtual imprisonment of the Naderi twin girls, Zahra and Massoumeh, aged twelve. Welfare agents take the girls into custody until their parents engineer their release by promising that the girls will be washed, taught some skills, and allowed to leave the family compound. The parents cannot keep these promises because the mother is blind and the father does not want to leave the girls "unprotected" when he leaves to beg and buy ice and bread. Frustrated, Mrs. Mohamed, the social worker, eventually locks him in behind the same barred, inner gate that has confined the children. In the midst of the dispute, the girls are released on the streets of Tehran, where they have a series of adventures and begin a tentative education in social relationships. The film ends with Mrs. Naderi stumbling alone out of the house onto the street, where a boy in an upstairs window taunts her with an apple dangled on a string. She finally seizes the apple.

All of the family members play themselves. The writing of the script followed rather than preceded each of the eleven days of filming, which meant that the family actively influenced the shape of narrative. Makhmalbaf indicates that some events are fictional, such as the locking up of the father by the social worker. However, key symbolic elements, such as the girls' fascination with apples, emerged from "the children's own world" at the time of filming. ${ }^{39}$ The girls thus contributed to the diegesis through their spontaneous actions and choice of props. Because Makhmalbaf entered the drama as it was still unfolding, the girls' experiences are captured while they are adapting to the outside world. This sense of immediacy is enhanced by the use of a handheld camera, which, for example, follows the girls down the street on their first escape.

In reality, and against the expectations raised by their physical liberation at the end of the film, social workers subsequently placed Zahra and Massoumeh in a new home and Mrs. Naderi died. ${ }^{40}$ These are sobering reminders that the film-despite its temporal proximity to and eventual participation in the events, the authenticating effect of the camera work, and the active contributions of the actors-is ultimately conceived and realized as a finite narrative drama. Makhmalbaf asserts rather disingenu- 
ously, "I don't judge, I just show things as they are. Let people look at themselves and see what is wrong and what is right; if they want to change, they can." ${ }^{11}$ In fact, the use of repeated motifs-plants, hands, apples, and mirrors, discussed below-define this as a poetic realist film, in which symbolic elements are interwoven to imply an extradiegetic narrative perspective.

However, the presentation of Mr. Naderi reflects Makhmalbaf's insistence on the emotional complexity of her characters. The film juxtaposes the girls' neglect and incarceration with the father's distress, articulated through invocations of God and pleas about poverty and his wife's blindness. While the patriarchal precepts on which he bases his life are presented as outmoded, they are given weight, albeit ironically, through his reading from popular street texts such as "Advice to Fathers." The imaginary community provided by religion and tradition is figured, with pathos, as inadequate compensation for the family's exclusion from a rapidly changing society. Nevertheless, there is an evident hypocrisy in the father's position; while the camera witnesses him locking the girls in every day, he blames their incarceration on his wife.

More elliptically, the girls' social emancipation is presented as also fraught with ambivalence. Mrs. Mohamed and the father insist that the girls need to learn social skills in order to marry, and the social worker gives them each a comb and a mirror. If these represent the demands placed upon public female identity, self-presentation, and modesty, in particular, then the girls' insistence on reflecting everything in their mirrors, from the lock on the gate to the neighborhood goat, is a disarming deflection of their symbolic purpose. (The young boy selling ice cream also becomes absorbed in combing his hair.) The film focuses on marginalization but implies, simultaneously, that full participation in society may bring dubious privileges. Similarly the lures of the outside world - apples, ice cream, and watches - are rarely accessible, at least not without money. ${ }^{42}$

This context of urban poverty, illiteracy, and family disability works to explicate, if not justify, the parents' treatment of Zahra and Massoumeh. The family is thrown into relief as a particular case via a backdrop of social and economic diversity in the neighborhood; the resourcefulness of the female social worker 
and the interventions of the women neighbors render the trope of female incarceration relative. The Apple is troubling, nevertheless, in its presentation of Mrs. Naderi. When asked about obtaining the parents' permission to recreate the twins' experiences, Samira Makhmalbaf has said only that the father was the relevant source of authority. ${ }^{43}$ Mrs. Naderi is blind, illiterate, and verbally abusive. Because she speaks a Turkish dialect, she can communicate with neither the neighbors nor the social workers. ${ }^{44}$ In the opening scenes, she forces her daughters to conceal not only their faces and heads but even their eyes, implying not only that girls are vulnerable to the gaze of others, but that a visual relationship with the world is inherently dangerous. Given the symbolic equation of apples with freedom (however ambivalently inscribed this is), the early close-up on Mrs. Naderi's hand as it grips an arm of each girl, one of which limply holds an apple, metonymically represents the mother as an incarcerating rather than liberating force.

In the closing minutes of the film, Mrs. Mohamed leaves the gate open as a lure for the mother to emerge after the departure of her husband and daughters. Mrs. Naderi deliberates anxiously on both the inner and outer thresholds of the house. She looks at herself in the mirror, her reflection denoting the disparity between what the camera and spectator perceive and what she herself can see. When she stumbles into the street and calls for her daughters, she is teased by an apple, raised and lowered on the string by the boy in the opposite window. The final, frozen frame, in which she finally grasps the apple, suggests an epiphany of understanding facilitated by the intervention of outsiders (social workers and, arguably, the film crew). Her muttered refrain, "Come here. Don't let go of the children. Come home. Take the children by the arm," has no audience within the diegesis but, I suggest, echoes beyond the final frame.

Makhmalbaf presents both mother and daughters as physically and verbally disabled females in a traditionalist, poor subsociety, victims of a seemingly insurmountable set of discriminations. Mrs. Naderi's physical disempowerment through blindness extends to her overall silencing in the dispute that rages between Mr. Naderi and Mrs. Mohamed; her only mode of intervention is to swear at both them and the girls. However, the thematic asso- 
ciation between vision, voice, and power is displaced to the focus on the twins who, cut off from contact with society, cannot speak properly and are impaired in their physical movement. Corresponding with Mrs. Naderi's inability to defend herself verbally is the fact that she cannot see what is being filmed and so can function only as filmed object. When she mumbles frequently that she is scared, the film does not explore the nature and cause of her fear. Thus, while there is a constant sympathetic focus on Zahra and Massoumeh, who incarnate the symbol of the stunted plant that opens the film, no empathy is sustained with their mother and, at the end of the film, Mrs. Naderi's situation has not improved with that of her daughters. When Mrs. Mohamed encourages her to seek help, she struggles to free her hand, but the motives for her resistance are not pursued. It appears that the camera is experienced as another traumatic intrusion, given that Mrs. Naderi remains off-screen, in the shadows of the house, or with her face completely covered. While the media are represented critically via microphones thrust at the girls in welfare and the reductive lampooning of Mr. Naderi in the newspaper, The Apple underplays the fact that it, too, consists of an encounter between filming and filmed subjects.

This elision becomes more troubling once the film enters the cross-cultural domain. There, the film is sanctioned as an authentic representation of social reality because, as Jasmin Darznik suggests, The Apple is "a story that the West has been waiting for Iran to tell about itself." 45 Trinh exposes a stubborn inclination to identify "the fundamental referent of the social" in cross-cultural viewing acts of any genre, a tendency that is exacerbated when visual texts purport to "catch reality on the run."46 This propensity has a substantial historical pedigree in which the political economy of the gaze is weighted unevenly. Fatimah Tobing Rony, mobilizing a Saidian frame of analysis and citing Claude Lévi-Strauss, describes how explorers, anthropologists, and cultural tourists have historically seen "what they already knew they would find, images predigested by certain "platitudes and commonplaces." "47 While anthropological discourses have undergone a self-reflexive turn, a range of commentators affirm that Islamic cultures and identities are still assigned a place out- 
side the teleology of progress. ${ }^{48}$ The tendency is exacerbated in relation to Muslim women, who are assumed to live at odds with dominant Islamic discourse, the law, the nation-state, historical archives, and technology. As such, female experience is construed metonymically, rendering women as ethnographic objects rather than historical subjects. ${ }^{49}$

It is within this epistemological framework that we can interpret what Darznik encapsulates as the predominant reaction to the then seventeen-year-old Samira Makhmalbaf, whose "very presence [at Cannes] seemed a paradox. . . . Was Iran a country that imprisoned girls in their homes or a country that set them free to make films of international repute?"50 Makhmalbaf's subsequent work has clarified her intrinsically skeptical attitude toward existing representational frameworks in Iran and beyond. In At Five in the Afternoon, the discourse of the Koran is explicitly revealed as alienating for the female protagonist who is struggling, like the setting of post-9/11 Afghanistan, to come into independent being. However, her futile attempts to gain access to the rhetoric of female politicians (such as Indira Gandhi) suggest a wider impoverishment of discursive frameworks for female agency. More holistically, the virtual realism of Blackboards (Takhté siah) (Iran/Italy/Japan, 200o), set on the amorphous borders of Iran and focused on a black and blank canvas on which nothing is successfully named, disables assumptions that represented objects can be transmuted into useable statements about social reality.

In the docudrama Divorce Iranian Style, Kim Longinotto and Ziba Mir-Hosseini self-consciously respond to the challenge of representing contemporary Iranian women. The idea for the film originated with Longinotto, a British director whose work is characterized by collaborative filmmaking, the use of an all-woman crew, and the portrayal of non-Western cultures. Longinotto was interested in the lack of fit between the culture presented in Iranian art films and the "demonized view of Iranian people in England" that prevailed in the early $199 \mathrm{os}$. She was particularly motivated to collaborate with Mir-Hosseini, an Iranian now resident in Britain, after reading Mir-Hosseini's Marriage on Trial (1993), an anthropological study on women and sharia law. ${ }^{51}$ 
Divorce is set predominantly in one family court in central Tehran. It was filmed over a period of four weeks for Britain's Channel 4 and consists of a series of legal cases in which women file for divorce, alimony, and child care. The film was imbricated from its inception in a cross-cultural politics of representation: the $\mathrm{BBC}$ refused the project, arguing that British audiences are resistant to subtitled documentaries and that the veiled protagonists of the drama were too "anonymous" and not "sexy" enough (25). Furthermore the Iranian government, uneasy about muchpublicized divorce rates and deteriorating family values in the West, first rejected the film proposal. Commissioning editor Peter Moore commented wryly that, from its inception, the project felt "like a forced marriage." 52 Mir-Hosseini recalls that most people "wanted us to change our theme, to film a 'politically correct' issue which reflected a 'positive image' of Iran, such as marriage ceremonies, female members of parliament, or mothers of martyrs"; the directors responded that a foregrounding of the subject of martyrdom would only contribute to sensationalist expectations about Iran (181, 173).

This prefilmic negotiation helped the directors to clarify their presentation of the project and the representational politics that it entailed. They decided to focus on personal and social complexity - what they hoped were universal, albeit culturally inflected, concerns. By producing "powerful yet non-judgmental narratives," they wanted to foreground individual experiences of specific sociolegal realities and thus to complicate assumptions about Iran as a special or extreme context of gendered politics. Divorce presents the cases of six women, four of which-those of Massy, Ziba, Jamileh, and Maryam-are developed in detail. MirHosseini explains the editing principle:

We tried to focus on commonalities rather than on the exotic and the different, to remind the viewer that marriage is a difficult institution ... that societies and individuals deal with this in different ways. . . . We also wanted ... to give glimpses into the lives of ordinary people. Above all, we wanted to let the women speak, to show them as individuals going through a difficult phase in their lives and to communicate the painand the humour-involved. (191) 
Standards of privacy were enforced throughout; none of the litigants (including husbands) are shown without prior consent. The focus on a single court enables the directors to "focus on characters and develop storylines" or "self-contained" narratives. ${ }^{53}$

As the courthouse is defined as masculine space, the allfemale crew (all of whom observed hijab) are assumed by the female litigants to be "on the right side"; as such, they often smile, wink at, and appeal directly to the film crew as witnesses. ${ }^{54}$ MirHosseini indicates that the two directors present themselves as two facets of the same person, with herself as culturally, linguistically, and legally fluent mediator and confidante, and Longinotto in a more detached, discrete role. Mir-Hosseini consistently held her face at the same level as Longinotto's camera, and the two women never spoke to each other in court except where remarks explicitly addressed to Longinotto required translation. The directors do not, however, attempt to erase their presence from the film, in which their voices remain audible on the soundtrack as well as in the framing voice-overs. 55

For Mir-Hosseini, Divorce is loaded with both personal and professional freight. In Islam and Gender, she explains,

I found myself in an uncannily familiar situation of shifting perspectives and self-redefinition: as well as refocusing my views on the complex politics involved in the representation of women, I once more had to confront, articulate, and honor my own multiple identities. During my debates with clerics in Qom [for research toward Islam and Gender], I had to justify my feminism; now I wanted to articulate the Muslim and Iranian aspects of my identity [to British television executives and Iranian officials]. ${ }^{56}$

Mir-Hosseini has gained a heightened awareness of the performative nature of identity. When she met women outside the court during her own divorce proceedings, she remembers, "I often started by relating how my own marriage broke down and how I obtained my divorce . . . I soon noticed that every time I told my story it sounded different: I emphasized parts of my experience that related to those of the women I was talking to. I became increasingly sensitive to situations; to how different contexts produce 
different narratives, how one can control this production, how much depends on one's perspective" (xiv). Divorce was presented in Channel 4's True Stories series and is offered to Western audiences as a previously undiscovered "angle of vision" on Iran. However, Mir-Hosseini's third-eye perspective implicates herself as not only a mediating subject. ${ }^{57}$ Her discourse interacts with those of women experiencing social and legal conflicts similar to her own; as indicated above, the project encourages other women to articulate aspects of her Muslim and Iranian identity in her place. This reverses the authoritative balance implicit in a project that purports to "let women speak." Further, both directors commit themselves as actors in the drama. After a dramatic off-camera scene in which Maryam rips up a court order to hand over maintenance of her child, the directors refuse to testify against her. ${ }^{58}$ This incident signals a rejection of an objective position and aligns the directors in subversive solidarity with Maryam against the law.

The film makes a vital ideological intervention in its presentation of official discourses as permeable. By persistently and even aggressively engaging with the law, women across the social spectrum are shown actively to participate in contemporary debates on gendered rights in Islamic Iran. As in Panahi's Circle, women battle a frustrating and contradictory system, but here the protagonists mobilize a range of creative strategies. Massy publicly exposes her husband's sexual shortcomings and beguiles the court officials in order to reclaim her "lost" legal papers. Sixteenyear-old Ziba asserts her legal right to continue studying while married and openly manipulates her husband by threatening to file for abuse. Jamileh uses the court session merely to "teach [her husband] a lesson," as she has no intention of divorcing him. Women are not revealed as hopelessly oppressed but as an articulate force. The final voice-over, superimposed on the face of each of the main characters in slow motion, indicates that all have achieved some degree of success in their dealings with the court.

As Tobing Rony suggests, by foregrounding the resistant and collaborative practices of filmed subjects, ethnography becomes exponentially more enabling. As she states, the "third eye turns on a recognition: the Other perceives the veil, the process of being visualized as an object, but returns the glance. The 
gesture of being frozen into a picturesque is deflected." 59 Nevertheless, while the makers of Divorce claim "the subject position of the listener" instead of "the dominant position of the gazer/criticizer," 60 the two modes of cultural encounter are never entirely separated. A subjective bias is implicit in the dominant thematic and camera focus on women, and, in one instance, Mir-Hosseini criticizes Ziba's husband for marrying a young girl. The crew's partiality constitutes an insertion of values-albeit occasional and provoked by events such as Maryam's torn paper-into the cultural space of the diegesis. ${ }^{61}$ Despite the useful undermining of the authoritative distance of the filmic apparatus, it may be construed that the film team is instrumental to the outcome of cases that are ordered into narrative closure. Thus, as in The Apple, editing and structuring practices are complicit in the processes of representation. Further, Longinotto's camera does not altogether resist voyeurism. In a case not extensively covered, one woman shields herself from the camera with her face veil, which does not prevent the camera from focusing on her hidden profile and the hand that holds her veil in place. The informing discourse of the film is further revealed through the juxtaposition of court scenes with those in the mosque at prayer time and with shots outside, in which the late Ayatollah Khomeini's portrait looms large on a billboard, thus linking religion, politics, the law, and patriarchal dominance. However, a nuanced scene is included in which female officials outside the courts monitor the attire of the women who enter judicial proceedings. Although the court women strictly monitor the hair and makeup of the claimants, their friendly tone and joking suggest some degree of ironic capitulation to the rules. When one woman removes her makeup, an official says jokingly, "Now you look like a real lady!" The court secretary, Mrs. Mohar, is an essential element in the presentation of a diverse range of female attitudes toward the law. Far from displaying solidarity with the women in court, she often disputes with, reprimands, and ignores them. Her young daughter Paniz functions in parodic contrast and is firmly biased in her perception of female innocence and respectability and "rubbish men" who "don't know how to live properly and correctly."

As Trinh observes, a common assumption in cross-cultural 
feminist documentary is that "those who are/need to be given an opportunity to speak up never had a voice before." 62 While Divorce foregrounds women's tenacity, the impact of the film rests, to some extent, on the surprise value that the women's creative tactics hold for non-Iranian viewers. The quality and sheer quantity of cultural difference that inheres in the court and familial procedures mean that assumptions about the "Islamic oppression of women" were inevitably confirmed for some viewers. John Anderson, for example, claims that "Divorce Iranian Style is easy to digest, once you grasp its most fundamental concept: Women under the kind of Islamic law practiced in Iran have no rights. After that, everything makes perfect sense." The same journalist employs orientalist terms to describe the "claustrophobic Islamic courtroom," "the barbaric legal legacy of the Khomeini era," and a "rigged" and inherently opaque legal system. In opposition, the women are cast as revolutionaries, coached and abetted by their British counterparts, in what he describes as "guerrilla-advocacy cinema." In sum, Iranian women "have to be so tenacious and resolute about even daring to bring their cases up within a system so oblivious to the concept of westernized justice that they assume heroic stature just by being there." 63 Anderson's comments, although extreme, suggest that the ethnographic object continues to be assimilated as "the real thing" despite efforts to complicate the association between the two terms.

Iranians at home and abroad may respond with a heightened sensibility to representations of Iranian culture. In 1999, Divorce was rejected by the prestigious Fajr Film Festival in Tehran on the grounds that permission had not been sought from all the main actors (in fact, all of the women had provided written consent before filming began). While some women's-rights activists supported the film, there was little consensus otherwise among viewers either in or outside the country. Critics suggested that the film was "staged" and the actors handpicked to produce a highly critical perspective on the status of women, thus exposing the Islamic Republic to Western critique. Others saw it as an indictment of sexist Islamic law or even as Iranian propaganda. MirHosseini concludes that negative reactions were differently moti- 
vated, but "rooted in a fear of being judged and misunderstood by the 'other'-the West," as well as symptomatic of a profound Iranian uncertainty about the current Islamic regime. ${ }^{64}$

Cross-cultural spectators do not merely consume but also contribute to the production of meaning in films. Laura Marks suggests that "as well as bearing meanings to the audience, [films] receive impressions from the people who have seen them. Intercultural cinema builds up these impressions like a palimpsest and passes them on to other audiences. The very circulation of a film among different viewers is like a series of skin contacts that leave mutual traces." 65 This transfer of meaning is not just emotive, tactile, or aesthetic, however. As Trinh points out, documentary film posits a "real" which must be legitimized as such by the spectator. ${ }^{66}$ Trinh's comment reminds us that the nonnative spectator always already has expectations, so that, as Poonam Arora comments, simplistic and stereotypical representations are the kind most easily read by mainstream Western audiences. ${ }^{67}$ In light of these observations, Marks's model of a "mutual" cinematic contact conceals the trace of epistemological violence that so often inheres.

That said, it is difficult for a Western viewer to disavow one's own limitations in interpretting Iranian cinema. Contemporary Iranian art cinema preempts and resists imposed meanings by actively engaging with ideas of perception and representation. It consistently grounds its thematics in the local and makes few allowances in terms of cultural explication; there is a tendency to refuse conventional narrative closure and to manipulate spectator response. It should, as a result, be difficult for Western viewers to maintain the fiction that they are "the privileged decoders and ultimate interpreters of meaning." 68

I suggest that contemporary Iranian cinema should be engaged with full attention to the "translation effects," which shift and resettle as the films are disseminated across national borders. Rather than confining our conception of translation to the literal activity (for example, the use of subtitles to frame Iranian films for European and US audiences), it is helpful to think of films as Sherry Simon does: as "documents which exist materially and move about, add to our store of knowledge, and contribute 
to ongoing changes in esthetics." As texts, films are also "writing practices fully informed by the tensions that traverse all cultural representation." 69 Translated across national and cultural boundaries, these films inevitably participate in a process of representation that may reinforce but ideally will mediate these tensions in the international domain.

\section{Notes}

1. While Iran has never been colonized, structural similarities to a colonial situation in its twentieth-century history enable a postcolonial frame of analysis. The ideological positioning of the state since 1979 has been dialectically defined by the economic exploitation of the country by Europe and the US and their perceived cultural hegemony prior to the overthrow of the Shah.

2. Laura Mulvey, "Afterword," in The New Iranian Cinema: Politics, Representation and Identity, ed. Richard Tapper (London: I. B. Tauris, 2002), 257.

3. In the current climate of hostilities between Islam and the West, this claim does not require extensive elaboration. For detailed analysis of media representations of Iran through the $1980 \mathrm{os}$ and 1990s, see Edward Said, Covering Islam: How the Media and the Experts Determine How We See the Rest of the World, rev. ed. (New York: Vintage, 1997), particularly chapter 2.

4. Trinh T. Minh-ha, When the Moon Waxes Red: Representation, Gender, and Cultural Politics (New York: Routledge, 1991), 29.

5. While the director is a fictional character, one can speculate that he "stands in" for Kiarostami (see page 9). A more extreme blurring of intra- and extradiegetic roles is manipulated in Kiarostami's Close-Up (Nema-ye Nazdik) (Iran, 199o), in which director Mohsen Makhmalbaf plays a fictionalized version of himself.

6. The first two films are Where Is My Friend's House? (Khane-ye doust kodjast) (Iran, 1987) and And Life Goes On . . (Zendegi vadigar hich) (Iran, 1991).

7. For an autobiographically inflected account of "haggling" or counterinterpellative strategies of Iranian cinema audience, see Hamid Naficy, "Theorizing 'Third-World' Film Spectatorship," Wide Angle 18 (1996): 3-26. 
8. Kiarostami quoted in Nassia Hamid, "Near and Far," interview with Abbas Kiarostami, Sight and Sound, February 1997, 22, 24, original emphasis. Kiarostami's principle of distanciation is influenced by taazieh, folk theater that depicts the murder of Iman Hossein, the Prophet's son.

9. Azadeh Farahmand, "Perspectives on Recent (International Acclaim for) Iranian Cinema," in Tapper, The New Iranian Cinema, 99, 100-101.

10. Trinh, When the Moon Waxes Red, 43 .

11. Negar Mottahedeh, "Framed Unframed" (paper presented at the conference "Behind the Lens, Beyond the Veil: Women in Iranian Cinema," School of Oriental and African Studies [SOAS], London, 5 May 2001).

12. Mary Ann Doane, Femmes Fatales: Feminism, Film Theory, Psychoanalysis (New York: Routledge, 1991), 48, 275 n5.

13. Information about changes in the relationship between the state and Iranian cinema is taken from Reza Allamehzadeh, "Iran: Islamic Visions and Grand Illusions," trans. John O'Kane, in Film and Censorship: The Index Reader, ed. Ruth Petrie (London: Cassell, 1997), 129-32; Hamid Naficy, "Iranian Cinema," in Life and Art: The New Iranian Cinema, ed. Rose Issa and Sheila Whitaker (London: NFT and BFI, 1999), 13-25; and Hamid Naficy, "Islamizing Film Culture in Iran: A Post-Khatami Update," in Tapper, The New Iranian Cinema, 26-65.

14. Naficy, "Islamizing Film Culture," 53.

15. Hamid Naficy, "Veiled Vision/Powerful Presences: Women in Post-Revolutionary Iranian Cinema," in Issa and Whitaker, Life and Art, $5^{\mathrm{O}}, 5^{1}$. Women continue to be commodified in marriage contracts, however, as Divorce Iranian Style attests.

16. Fatima Mernissi's argument, that women's sexual power threatens fitna or social chaos in the Muslim cultural imaginary, resonates here. See Mernissi, Beyond the Veil: Male-Female Dynamics in Contemporary Muslim Societies (London: Al Saqi, 1975).

17. Afsaneh Najmabadi, "Hazards of Modernity and Morality: Women, State, and Ideology in Contemporary Iran," in Women, Islam, and the State, ed. Deniz Kandiyoti (Hampshire, UK: Macmillan, 1991), 65. Najmabadi deploys the term gharbzadegi, which she translates as "westoxication or weststruckness" (ibid., 
64). The term is taken from Jalal Al-e Ahmad, Gharbzadegi (Weststruckness), 2nd ed., trans. John Green and Ahmad Alizadeh (Costa Meca, CA: Mazdâ, 1997). Al-e Ahmad's essay was originally published in Iran in 1962.

18. Minoo Moallem, "Transnationalism, Feminism, and Fundamentalism," in Between Woman and Nation: Nationalisms, Transnationalisms, and the State, ed. Caren Kaplan, Norma Alarćon, and Minoo Moallem (Durham, NC: Duke University Press, 1999), 329, $33^{1}$.

19. Anne-Emanuelle Berger, "The Newly Veiled Women: Irigaray, Specularity, and the Islamic Veil," Diacritics 28 (1998): 103. The main requirements of hijab in Iran are that the hair and upper body are fully covered. The black chador remains a common, but not the only, solution.

20. Naficy, "Veiled Vision/Powerful Presences," 49.

21. Hamid Naficy, "Parallel Worlds: Shirin Neshat's Video Works," in Shirin Neshat: Exhibition Catalogue, ed. Gerald Matt and Julia Peyton-Jones (Vienna: Kunsthalle, 200o), 47. For a discussion of Neshat's visual texts on "Women and Islam," see my "Frayed Connections, Fraught Projections: The Troubling Work of Shirin Neshat," Women: A Cultural Review 13 (2002): 1-17.

22. For example, Nima Naghibi, "Bad Feminist or Bad Hejabi?" Interventions: Journal of Postcolonial Studies 1 (1999): 568, explains that the andaroon, which earlier signified women's space in the home, now demarcates the private domestic space in its entirety, due to the enforcement of veiling and gender segregation outdoors. She describes the home as a locus of resistance, in which a multitude of forbidden activities (such as drinking, dancing, and watching imported videos) take place.

23. See Maryam Azad, "Sisters of Darkness," Index on Censorship 29 (April 200o): 6o-65.

24. Naficy, "Veiled Vision/Powerful Presences," 45-47. See also Shahla Lahiji, "Chaste Dolls and Unchaste Dolls: Women in Iranian Cinema since 1979," in Tapper, The New Iranian Cinema, 215-26.

25. Ziba Mir-Hosseini, Islam and Gender: The Religious Debate in Contemporary Iran (London: I. B. Tauris, 2000), 7.

26. Hadani Ditmars, "Interview with Bani-Etemad," Sight and Sound, January 1999, 20. 
27. Mamad Haghighat, Histoire du cinéma iranien, I9oo-I999 (Paris: Bibliothèque d'information, 1999), 41-42. According to Naficy, "Theorizing 'Third-World' Film Spectatorship," 14, audiences have always split along class lines.

28. Stephanie Scott, "Tahmineh Milani Talks Back: A Feminist Filmmaker Forges Ahead and Fights for Freedom in Iran," NewEnglandFilm.com, 1 December 2001, www.newenglandfilm .com/news/archives/ordecember/milani.htm.

29. Tahmineh Milani, from an address to the audience before a screening of Two Women at Barbican Centre, London, 6 May 2001.

3o. Farahmand, "Perspectives on Recent Iranian Cinema," and Hamid Reza-Sadr, "Contemporary Iranian Cinema and Its Major Themes," in Issa and Whitaker, Life and Art, 43.

31. Hadani Ditmars, "Talking Too Much with Men: Hadani Ditmars on Iranian Film-making," Sight and Sound, April 1997, 11.

32. Stuart Hall, "When Was 'the Post-Colonial'? Thinking at the Limit," in The Post-Colonial Question: Common Skies, Divided Horizons, ed. Iain Chambers and Lidia Curti (London: Routledge, 1998), 249.

33. The wider import of Islamic veiling in relation to feminism is a well-trammeled issue. See Naghibi, "Bad Feminist or Bad Hejabi?" for a particularly rich intervention.

34. Gayatri Chakravorty Spivak, "Poststructuralism, Marginality, Postcoloniality and Value," in Literary Theory Today, ed. Peter Collier and Helga Geyer-Ryan (Ithaca, NY: Cornell University Press, 1990), 219-44; quoted in Naghibi, "Bad Feminist or Bad Hejabi?" 569 .

35. Mir-Hosseini, Islam and Gender, 8.

36. Azadeh Farahmand, "From Rape to Reverence: An Unprecedented Female Type in Bahram Beyza'i's Killing Rabids" (paper presented at "Behind the Lens, Beyond the Veil," SOAS, London, 5 May 2001).

37. See in particular Huma Ibrahim, "Ontological Victimhood: 'Other' Bodies in Madness and Exile-Toward a Third World Feminist Epistemology," in The Politics of (M)Othering: Womanhood, Identity, and Resistance in African Literature, ed. Obioma Nnaemeka (London: Routledge, 1997), 147-61. 
38. Samira Makhmalbaf's father, Mohsen, one of the leading directors in contemporary Iranian cinema, was scriptwriter and editor on this and her subsequent films. Her stepmother, Marziyeh Meshkini, director of The Day I Became a Woman (Roozi khe zan shodam) (Iran, 200o), was assistant director on The Apple and At Five in the Afternoon (Panjé asr) (dir. Samira Makhmalbaf, Iran/France, 2003).

39. Samira Makhmalbaf quoted in Sheila Johnston, "Quietly Ruling the Roost," Sight and Sound, January 1999, 19.

40. John Mount, "The Apple/Sib/La Pomme," Sight and Sound, January 1999, 41; Nasrin Rahimieh, "Born into Apprehension: An Analysis of Samira Makhmalbaf's The Apple" (paper presented at "Behind the Lens, Beyond the Veil," SOAS, London, 5 May 2001). Samira Makhmalbaf does not refer to the mother's death in the 1999 Johnston interview, "Quietly Ruling the Roost."

41. Makhmalbaf quoted in Johnston, "Quietly Ruling the Roost," 18.

42. Jasmin Darznik, "Shining Rotten Apple," Iranian, 3 March 1999, www.iranian.com/JasminDarznik/March99/Apple/.

43. Johnston, "Quietly Ruling the Roost," 18.

44. I am indebted to Rahimieh, "Born into Apprehension," for this biographical information.

45. Darznik, "Shining Rotten Apple."

46. Trinh, When the Moon Waxes Red, 37, 33 .

47. Fatimah Tobing Rony, The Third Eye: Race, Cinema, and Ethnographic Spectacle (Durham, NC: Duke University Press, 1996), 5 .

48. Marnia Lazreg, "Feminism and Difference: The Perils of Writing as a Woman on Women in Algeria," in Conflicts in Feminism, ed. Marianne Hirsch and Evelyn Fox Keller (New York: Routledge, 1990), 328. See also Amal Amireh, "Writing the Difference: Feminists' Invention of the 'Arab Woman,'” in Interventions: Feminist Dialogues on Third World Women's Literature and Film, ed. Bishnupriya Ghosh and Brinda Bose, 2nd ed. (New York: Garland, 1997).

49. This point is drawn from Tobing Rony, The Third Eye, 7, which uses Lévi-Strauss's schema of ethnographiable and historifiable documentary subjects. 
50. Darznik, "Shining Rotten Apple."

$5^{1 .}$ Longinotto quoted in Sarah Teasley, "Interview with Kim Longinotto," Documentary Box 16 (2000): 17; Ziba Mir-Hosseini, Marriage on Trial, A Study of Islamic Family Law: Iran and Morocco Compared (London: I. B. Tauris, 1993).

52. Moore quoted in Ziba Mir-Hosseini, "Negotiating the Politics of Gender in Iran: An Ethnography of a Documentary," in Tapper, The New Iranian Cinema, 181.

53. Teasley, "Interview with Kim Longinotto," 21; Mir-Hosseini, "Negotiating the Politics of Gender," 183.

54. Teasley, "Interview with Kim Longinotto," 19-20.

55. Mir-Hosseini, "Negotiating the Politics of Gender," 189, $185,191$.

$5^{6 .}$ Mir-Hosseini, Islam and Gender, xviii.

57. Teasley, "Interview with Kim Longinotto," 25.

58. Mir-Hosseini, "Negotiating the Politics of Gender," 189.

59. Tobing Rony, The Third Eye, 213.

6o. This distinction is made by Gwendolyn Audrey Foster, "Third World Women's Cinema: If the Subaltern Speaks, Will We Listen?" in Ghosh and Bose, Interventions, 217.

61. See Teasley, "Interview with Kim Longinotto," 22-23, for other interventions by the directors.

62. Trinh, When the Moon Waxes Red, 6o, original emphasis.

63. John Anderson, "Divorce in Iran," Iranian, 12 September 1998, www.iranian.com/News/Dec98/divorce.html (accessed 11 October 2004).

64. Mir-Hosseini, "Negotiating the Politics of Gender," 193-95.

65. Laura U. Marks, The Skin of the Film: Intercultural Cinema, Embodiment, and the Senses (Durham, NC: Duke University Press, 2000), xii.

66. Trinh, When the Moon Waxes Red, $3_{6}$.

67. Poonam Arora, "The Production of Third World Subjects for First World Consumption: Salaam Bombay and Parama," in Multiple Voices in Feminist Film Criticism, ed. Diane Carson, Linda 
Dittmar, and Janice R. Welsch (Minneapolis: University of Minnesota Press, 1994), 303.

68. Teshome Gabriel, "Towards a Critical Theory of Third World Films," in Questions of Third Cinema, ed. Jim Pines and Paul Willemen (London: BFI, 1989), 38-39; quoted in Arora, "The Production of Third World Subjects," 302.

69. Sherry Simon, Gender in Translation: Cultural Identity and the Politics of Transmission (London: Routledge, 1996), 7-8.

Lindsey Moore is lecturer in English at Lancaster University, UK. She has published articles on Algerian revolutionary women in the texts of Frantz Fanon and Gillo Pontecorvo and on Shirin Neshat, an Iranian artist resident in the United States. She is currently completing a monograph on the representation of Arab/Muslim women in contemporary literature and visual media.

Samira Makhmalbaf's The Apple (Sib) (Iran/France, 1998).

Courtesy Artificial Eye

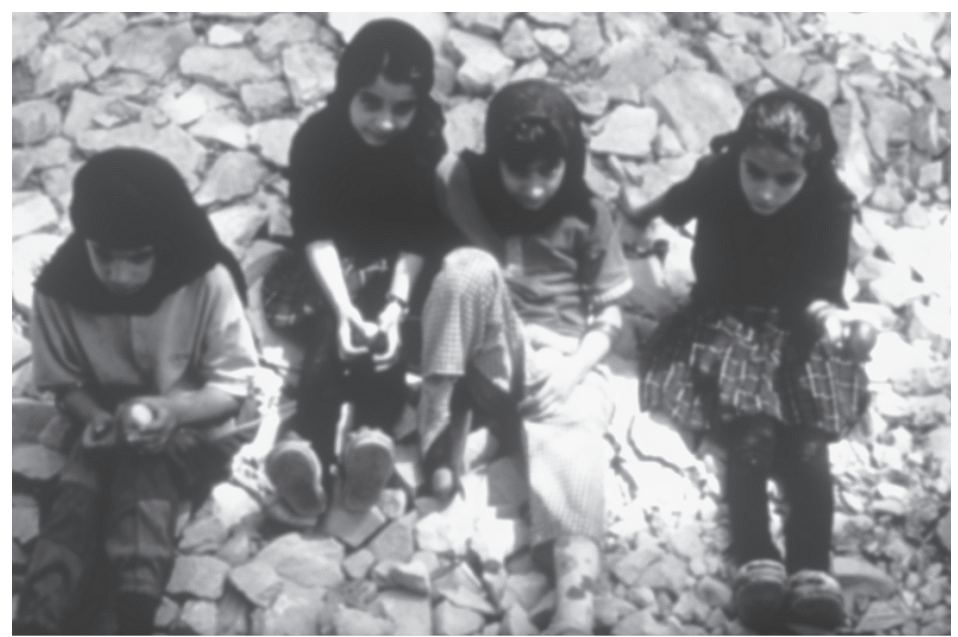

